\title{
ACCESS TO FINANCE AS A FUNDAMENTAL COMPONENT OF GLOBAL POLICY AGENDA: CASE OF THE BALTIC STATES
}

\author{
Ramona RUPEIKA-APOGA \\ University of Latvia, Latvia
}

\begin{abstract}
Access to finance for companies represents the theme of a strong interest in academic literature, evidenced by the large number of studies addressing this problem. The study illustrates thorny issues in companies financing and the crucial importance of addressing concerns of public authorities regarding improving availability of financial services. The study results highlight the need to recognize that countries require sound and well-functioning financial markets. Only in this case financial markets can provide much needed sources of investments such as sound banking loans, properly regulated securities exchanges, venture capital, and other resources.
\end{abstract}

Keywords: Access to finance; Financial market efficiency; Supervision; Financial inclusion

\section{INTRODUCTION}

Expanding access to financial services by SMEs is a critical objective of the financial inclusion agenda. The G-20 has started focusing on financial inclusion in the global policy agenda since 2009 and has identified financial inclusion as a key driver of economic growth, reduced economic vulnerability for individual households, poverty alleviation, and improved quality of life for people around the world. SME access to finance is a fundamental component of this agenda (Ardic, et. al. 2011). In the Baltic States SMEs form the largest part of companies, providing the majority of jobs. Nevertheless, SMEs commonly follow "niche strategies," using high product quality, flexibility, and responsiveness to customer needs as a means of competing with large-scale mass producers (e.g., Hallberg, 2000; Snodgrass \& Biggs, 1996), many researchers have highlighted the shortage of financial resources and access to finance as one of the main barriers to SMEs innovation capacity. As a result Baltic companies find it difficult to obtain commercial bank financing, especially long-term loans, for a number of reasons, including lack of collateral, difficulties in proving creditworthiness, small cash flows, inadequate credit history, high risk premiums, underdeveloped bank-borrower relationships and high transaction costs.

On the other hand, backed by solid empirical evidence, development practitioners are becoming increasingly convinced that efficient, well-functioning financial systems are crucial in channelling funds to the most productive uses and in allocating risks to those who can best bear them, thus boosting economic growth, improving opportunities and income distribution, and reducing poverty (Fama, 1991; Mankiw et al1, 1995; Clas, 1990; Berger et al., 1993; Aghion et al., 2005).

Access to finance plays a significant role in the development of the company, while the company's development level is dependent on the availability of financial services; at the same time access to finance is dependent on the financial market development and vice versa, available financial services improve financial market efficiency. The author developed scheme of interactions of access to finance, companies' development and financial market development is offered in fig. 1 .

A well-considered and proper assessment of macroeconomic policy and data transparency; financial regulation and supervision; institutional and market infrastructure as well are the key ingredients of a sound financial market. As a result countries require sophisticated and well-functioning at the same time financial markets. Only at that case financial markets can provide resources for investments as sound banking loans, properly regulated securities exchanges, venture capital, and other resources. To 
accomplish all those functions, financial markets regulation has to be sustainable and wellfunctioning. Financial regulation and supervision has to be confident and reliable, available to protect market participants from external and internal shocks.

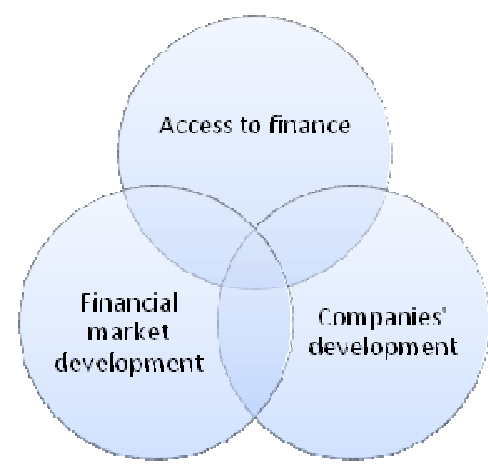

\section{Figure 1. The scheme of interactions of access to finance, companies' development and financial market development}

The study starts with a literature review in order to highlight the importance of financial services availability, from companies, and from financial market perspectives, then will go on to development of hypotheses. The analysis conducted in this paper is based on data and statistics provided mainly by the Baltic States Central banks, by certain empirical studies, by the World economic forum and World Bank data bases. Research methodology, analyses results and research model are in the third section. The results of the analyses will be discussed and recommendation will be provided for policy makers and academicians at the last section.

\section{LITERATURE REVIEW AND HYPOTHESES}

\section{Access to finance effect on the development of companies}

SME development is high on the reform agenda of many governments. A broad range of policies and programs target improvements in SME business environments, as well as financial support to SMEs (Pittsburgh Summit, 2009). Numerous studies based on various surveys highlight that access to finance is one of the most important obstacles in the way of companies' growth and development, especially in the case of small and medium enterprises (Peachey \& Roe, 2004; Beck et al., 2005a, 2005b; Beck \& Demirgue-Kunt, 2006; Meghane et.al.,2007; ECB, 2011). Numerous studies that use firm-level survey data demonstrate that access to finance and the cost of credit pose barriers to SME financing (Scholtens, 1999; Schiffer \& Weder, 2001; Galindo \& Schiantarelli, 2003; IADB, 2004; Beck et al., 2006; Beck \& Demirgue-Kunt, 2006; Beck et al., 2008b). For example, T. Beck et al. in the study "Financing Patterns around the World: Are Small Firms Different?" (2008a) found that smaller firms and firms in countries with underdeveloped financial and legal systems use less external finance, based on data from a firm-level survey in 48 countries. Similar results were found also in other studies:

- access to credit is one of the biggest constraints for SMEs in Colombia (Stephanou \& Rodriguez, 2008);

- lack of access to finance together with management, labour skills and regulation are the main constraints to growth of SMEs in the UK (Binks \& Ennew, 1997);

- inability to raise external finance in Slovenia is one of the main obstacles for the SME sector underdevelopment (Hutchinson, 2006);

- lack to access of external finance is one of the main problems in most of Central and Eastern Europe (Anderson et.al., 1997; Budina et. al., 2000; Gros \& Suhreke, 2000; Konings et. al., 2003). 
The results from the Feasibility study on new forms of EU support to Member States and Regions to foster SMEs Innovation Capacity report have highlighted the shortage of financial resources and access to finance as one of the main barriers to SMEs innovation capacity. (Pro Inno Europe, 2011)

This same conclusion has been reached by European Central Bank survey results:

European Central Bank Consultation among 7,532 firms, of which 6,941 had less than 250 employees:

- Access to finance was second ranked most pressing problem faced by SMEs in the Euro Area. (ECB, 2011)

Public Consultation on the effectiveness of innovation support in Europe: 1,000 companies (of which a large majority were innovative micro and small enterprises) and 430 innovation intermediaries found that:

- Lack of access to finance is viewed by enterprises as the main factor hampering innovation activities.

- Lack of access to finance is considered by institutional stakeholders as the principal barrier hampering enterprises bringing innovations to the market ( EC, 2009).

H1: Access to finance is one of the main obstacles to doing business in the Baltic States

\section{Development of financial markets effect on the access to finance}

The recent economic crisis has emphasized the need for efficient financial markets. Efficient financial markets that are sound and well-functioning play a vital role in the development of the country. A characteristic of efficient financial market is that it channels funds from the ultimate lenders to the ultimate borrowers in a way that the funds are used in the most socially useful manner (Fama, 1970; Leighton, 2005).

Improvement of financial market efficiency needs the revaluation of macroeconomic policy and data transparency; supervision and regulation of financial intermediaries and institutional and market infrastructure (IMF, 2000, 2007; BIS, 2012; IOSCO, 2010; IAIS, 2011). Macroeconomic policy and data transparency by strengthening responsibility and increasing the political risk can therefore enhance credibility. As a result companies will receive access to finance with lower borrowing costs and in general stronger support for sound macroeconomic policies by a well-informed public.

In accordance with World Economic forum' report financial market efficiency can be characterised by following factors:

- Availability of financial services;

- Affordability of financial services;

- Financing through local equity market;

- Ease of access to loans;

- Venture capital availability.

Factors characterising trustworthiness and confidence are following:

- Soundness of banks;

- Regulation of securities exchanges;

- Legal rights index

H2: Access to finance depends on Baltic financial market efficiency 


\section{METHODOLOGY}

\section{Research Goal}

In this paper the author aims to highlight importance of access to finance as a fundamental component of global policy by analysing difficulties faced by companies in securing financial resources, emphasizing the differences between the three Baltic States. Knowing the difficulties in companies financing is essential for policy makers in order to design and implement appropriate policy, which will help to improve the access to financing for companies and to develop national economy as well.

During development of the paper the generally accepted qualitative and quantitative methods of economic research were used including comparative analysis and synthesis, and graphical illustration methods.

\section{Sample and Data Collection}

The analysis conducted in this paper is based on data and statistics provided mainly by the Baltic States Central banks, by certain empirical studies, by the World economic forum and the World Bank data bases.

\section{Analyses and Results}

There are two main credit theories that determine credit expansion to firms and individuals. The "power" theories of credit have been formalized by R. Townsend (1979), P. Aghion and P. Bolton (1992), and O. Hart and J. Moore (1994, 1998). According to these theories lenders are more willing to extend credit, when they can more easily receive repayments, capture collateral, or even gain control of the company.

The "information" theories of credit have been pioneered by D. M. Jaffe and T. Russell (1976) and Stiglitz and Weiss (1981). According to the second view, what matters for lending is information. When lenders know more about borrowers, their credit history, or other lenders to the company, they are more willing to extend more credit.

S. Djankov, C. McLiesh, and A. Shleifer (2006) by studying the importance of information and power theories of credit in explaining the variation in the size of private credit markets around the world using a new data set on private credit institutions for 129 countries during the period 19782003, found that both creditor protection through the legal system and information sharing institutions are associated with higher ratios of private credit to GDP, but that the former is relatively more important in the richer countries.

Credit bureaus and credit registries are essential parts of the financial infrastructure that facilitates access to formal finance. By sharing credit information, they help reduce information asymmetries, increase access to credit for small firms, lower interest rates, improve borrower discipline and support bank supervision and credit risk monitoring.

The Doing Business getting credit indicator measures the legal rights of borrowers and lenders with respect to secured transactions through one set of indicators and the sharing of credit information through another. The ranking on the ease of getting credit is based on the percentile rankings on its component indicators: the depth of credit information index (weighted at 37.5\%) and the strength of legal rights index (weighted at 62.5\%) (see table 1)

The strength of legal rights index measures the degree to which collateral and bankruptcy laws protect the rights of borrowers and lenders and thus facilitate lending. Strong creditor rights expand the availability of loans. In Latvia, in accordance with Doing Business report, lenders have better legal protection during bankruptcy and reorganization of the debtor; they are more confident about the return of their investment in cases of default and therefore more willing to issue credits, whereas the situation in Estonia corresponds to the average level in Eastern Europe \& Central Asia region. Estonia and especially Lithuania have to amend current laws, improving protection for lenders and for borrowers. 
Table 1. Ranking on the ease of getting credit in the Baltic States, Doing Business 2013 report (Rank/185 countries) (World Bank, 2013)

\begin{tabular}{|l|c|c|c|c|}
\hline & Estonia & Latvia & Lithuania & $\begin{array}{c}\text { Eastern Europe \& } \\
\text { Central Asia }\end{array}$ \\
\hline Getting credit (rank) & 40 & 4 & 53 & - \\
\hline Strength of legal rights index (0-10) & 7 & 10 & 5 & 7 \\
\hline Depth of credit information index (0-6) & 5 & 5 & 6 & 5 \\
\hline $\begin{array}{l}\text { Public registry coverage (\% of adults) } \\
\text { Number of individuals } \\
\text { Number of firms }\end{array}$ & 0 & $\begin{array}{c}908374 \\
56993\end{array}$ & 24,4 & 17,3 \\
\hline $\begin{array}{l}\text { Private bureau coverage (\% of adults) } \\
\text { Number of individuals } \\
\text { Number of firms }\end{array}$ & $\begin{array}{c}33,4 \\
200000 \\
100000\end{array}$ & 0 & $\begin{array}{c}81,2 \\
22077143\end{array}$ & $\begin{array}{c}29,8 \\
24715 \\
24811\end{array}$ \\
\hline
\end{tabular}

The depth of credit information index measures rules and practices affecting the coverage, scope and accessibility of credit information available through either a public credit registry or a private credit bureau. For regulators, credit information systems provide a powerful tool for supervising banks and monitoring credit risk and credit trends in the economy. Regulators often use information from credit bureaus to assess whether current provisioning is adequate and to analyze developments in credit markets and interest rates. The results may guide changes in the legislation governing financial institutions. Research in Argentina, Brazil and Mexico found that credit registries played a valuable role in credit risk evaluation and in supervision, including in calculations of credit risk for capital or as a check on a bank's internal ratings ( Powell, A. et al.,2004). In 2008 the Bank of Latvia's registry of debtors was transformed into a full-fledged credit registry. It now collects both positive and negative information on borrowers, borrower guarantors and their obligations. The registry is also able to record more precise information, such as the type of settlement of the borrower's obligations and the date on which settlement of a delayed payment is registered. And the registry expanded its coverage from 3,5\% of adults in 2008 to $63,8 \%$ in 2013. In Lithuania both private bureau and public registry record the number of individuals and firms listed in registry with information on their borrowing history from the past 5 years. As a result Latvia needs to continue the started process of improving the registry of debtors, whereas Estonia has to be more active in this direction.

Entrepreneurs around the world face a range of challenges. Some of them are costs and paid-in minimum capital required for a small or medium-size limited liability company to start up and formally operate (see table 2).

Table 2. Ranking of the starting a business in the Baltic States, Doing Business 2013 report (Rank/185 countries) (World Bank, 2013)

\begin{tabular}{|l|c|c|c|c|}
\hline & Estonia & Latvia & Lithuania & $\begin{array}{c}\text { Eastern Europe \& } \\
\text { Central Asia }\end{array}$ \\
\hline Starting a Business (rank) & 47 & 59 & 107 & \\
\hline Procedures (number) & 5 & 4 & 7 & 6 \\
\hline Time (days) & 7 & 16 & 20 & 14 \\
\hline Cost (\% of income per capita) & 1,6 & 2,3 & 1,1 & 6,8 \\
\hline $\begin{array}{l}\text { Paid -in Min. Capital (\%of } \\
\text { income per capita) }\end{array}$ & 22,1 & 0 & 31,3 & 5 \\
\hline
\end{tabular}


Cost is recorded as a percentage of the economy's income per capita. It includes all official fees and fees for legal or professional services if such services are required by law. In the Baltic States all fees are significantly lower than the average in this region.

The paid-in minimum capital requirement reflects the amount that the entrepreneur needs to deposit in a bank or with a notary before registration and up to 3 months following incorporation and is recorded as a percentage of the economy's income per capita. Many economies require minimum capital but allow businesses to pay only a part of it before registration, with the rest to be paid after the first year of operation. The paid-in minimum capital recorded for Lithuania and Estonia $(31,3 \%$ and $22,1 \%$ of income per capita respectively) is very high.

In Fig. 2. are presented the responses of companies to inquiry of the most problematic factors of doing business in the Baltic States.

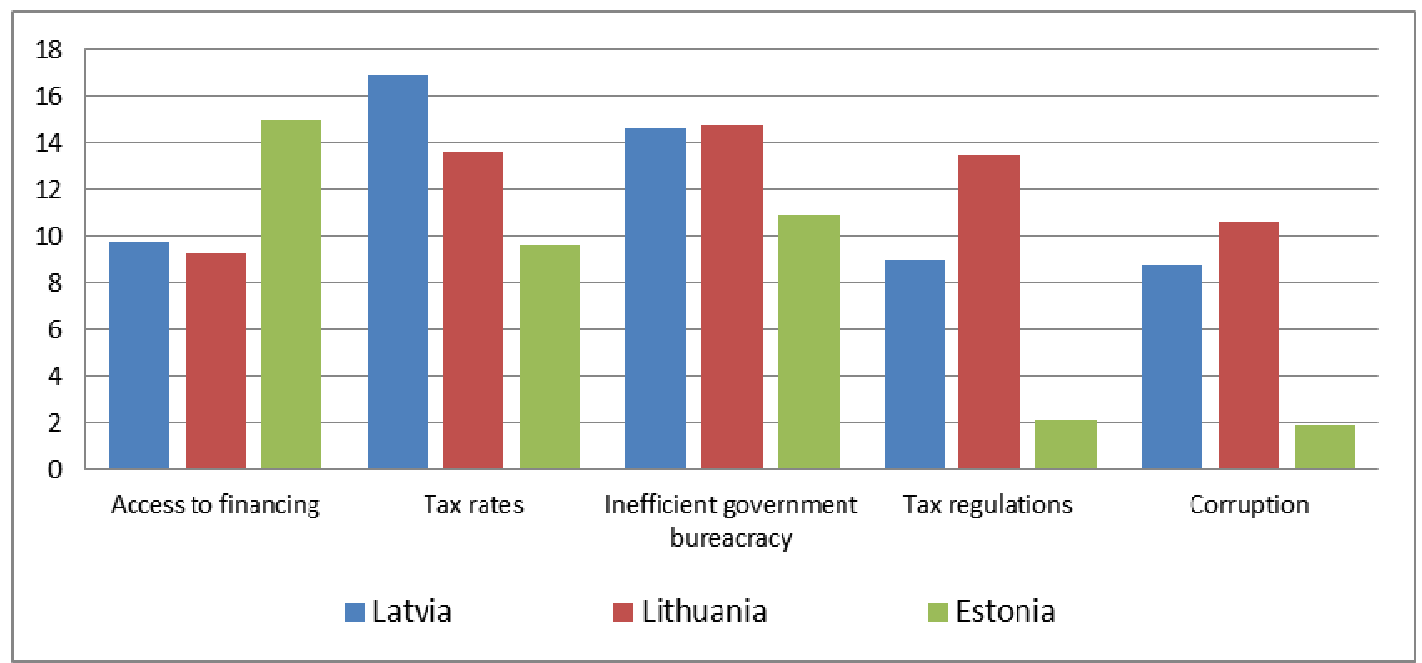

Figure 2. The main obstacles to doing business in the Baltic States 2012-2013, percent of responses (World Economic Forum, 2012)

Access to financing was the third ranked most pressing problem faced by Latvian entrepreneurs after too high tax rates and inefficient government. For Lithuanian entrepreneurs' access to finance was ranked as the six ranked obstacle, as they consider tax rates and tax regulations alongside with corruption and inefficient government more problematic. Access to financing was the second ranked obstacle to doing business in Estonia.

Analysing availability of financial services in the Baltic States in general, the author concluded that in Estonia companies and individuals have better access than in Latvia and Lithuania, ranking Estonia in 43 place (2012), within 45 best countries, at the same level as Slovak Republic and Czech Republic, and not far from Japan's and Israel's levels. Whereas Latvia's and Lithuania's positions are 65 and 74 respectively, placing Latvia at the same level as Jamaica and Colombia, and for Lithuania - Uganda and Zambia. Whereas access to finance is significantly better in Estonia, the affordability of financial services is rather similar in the all Baltic countries, placing Latvia and Estonia in 58 and 59 places out of 144 countries, and Lithuania in $73^{\text {rd }}$ place. 


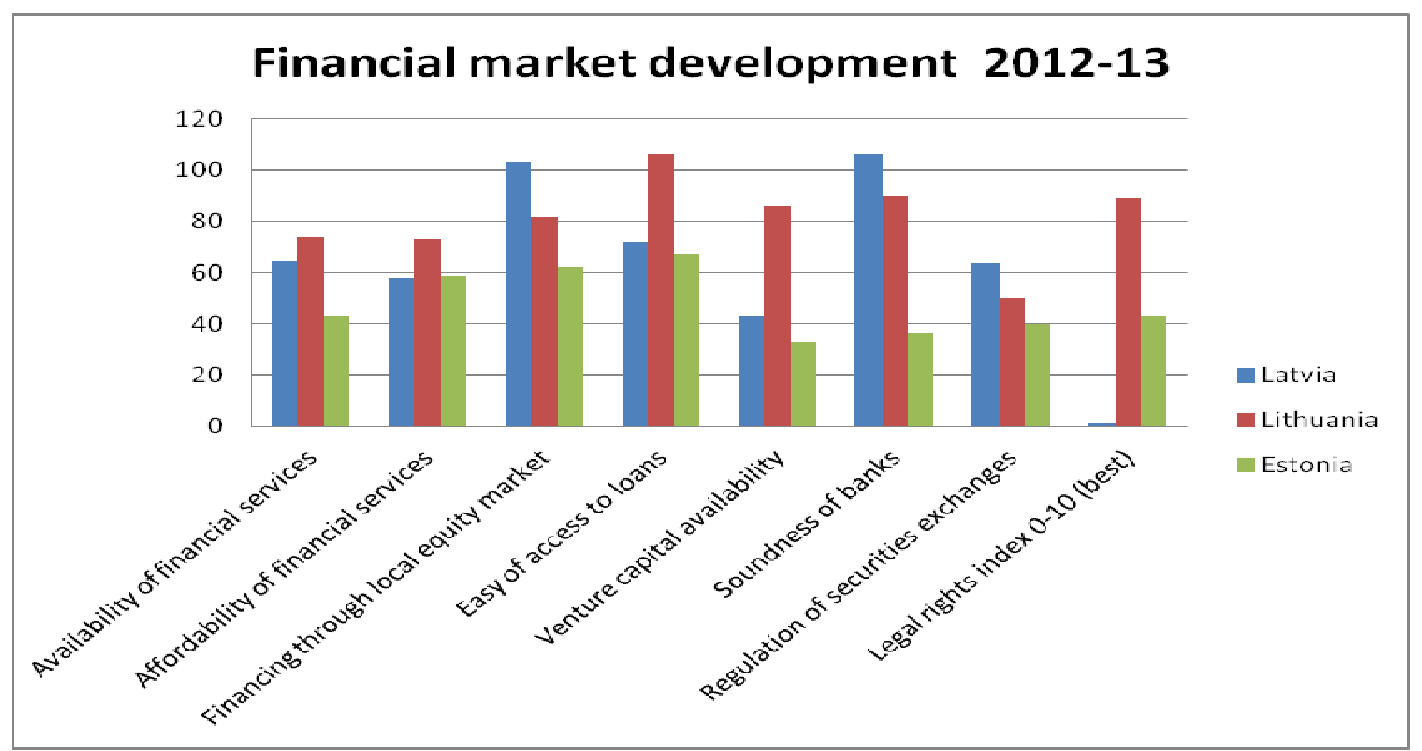

\section{Figure 3. Global Competiveness Index 2012-13 of financial market development} in the Baltic States, (Rank/144 countries) (World Economic Forum, 2012)

By evaluating the positions of the Baltic States in the world countries ranks, Latvia shows an improved affordability of financial services when compared with access to services, whereas in Estonia the situation is opposite, as for Lithuania in both determinants situation is the same. So, the results of the conducted analysis support $\mathrm{H} 1$ and $\mathrm{H} 2$ hypotheses.

\section{CONCLUSION}

Conducted empirical analysis proves that companies' access to finance in the Baltic States is a fundamental component of financial market efficiency and at the same time the access to finance is one of the most important obstacles to their functioning and development. As a result H1 (access to finance is one of the main obstacles to doing business in the Baltic States) and H2 (access to finance depends on the Baltic financial market efficiency) are fully supported.

The main caveats and directions for improvement for policy makers are as follows:

- business regulatory reforms including the reduction of administrative barriers and the strengthening of access to finance, as well as support for access to external markets and encouragement of greater inflows of foreign direct investment to export-oriented sectors.

- Stronger supervision and regulation of financial intermediaries;

- revaluation of institutional and market infrastructure.

For Latvia the most vital improvements have to be done in equity market (from financing through local equity market perspective, and from regulation of securities exchange perspective), as well as greater intensity of supervision of banking activities in order to avoid possible bankruptcy of banks (the case of the bank "Krajbanka" bankruptcy in 2011).

For Lithuania it is essential to ease access to loans. To do that, Lithuanian government needs to amend collateral and bankruptcy laws, protecting more the rights of borrowers and lenders and thus facilitating lending. Nevertheless, rather well established registry of debtors compared to other Baltic States, was not sufficient to avoid problems in the banking sector (bank "Snoras" bankruptcy in 2011), as a result a more intensive supervision of financial intermediaries is still recommended.

As for Estonia, improvements have to be made in credit information systems, and in legal protection for lenders and borrowers.

The current study is not free from limitations. Its current sample consists of World Banks Doing business and World Forum statistics of companies by years; therefore, these findings may have limited generalizability. Future studies that replicate the current proposal, including panel data of nonfinancial firms listed on Nasdaq OMX Stock Exchange, may provide a more complete picture or add further dimensions to the current findings. 


\section{REFERENCES}

Aghion, P. \& Bolton P. (1992). An Incomplete Contracts Approach to Corporate Bankruptcy. Review of Economic Studies. Vol. 59,pp. 473-494.

Aghion, P., Howitt, P. \& Mayer-Foulkes D. (2005). The Effect of Financial Development on Convergence: Theory and Evidence. The Quarterly Journal of Economics, MIT Press, vol. 120(1), pp. 173-222

Anderson, R. \& Chantal, K.(1997). Finance and Investment in Transition: Czech Enterprises, 19931994, IRES-Institut de Recherches, Department of Economics, Université Catholique de Louvain, Discussion Paper 9715, Louvain-la-Neuve.

Ardic, O., Mylenko, N. \& Saltane, V. (2011). Small and Medium Enterprises A Cross-Country Analysis with a New Data Set, The World Bank, Policy Research Working Paper 5538.

Bank for International Settlement. ( 2012), Core Principles for Effective Banking Supervision, BIS

Beck, T. \& Demirgüç-Kunt, A. (2006). Small and Medium-Size Enterprises: Access to Finance as a Growth Constraint, Journal of Banking \& Finance, Nr. 30, pp. 2931-2943.

Beck, T., Demirgüç-Kunt A., \& Peria, S.M. (2008b). Bank Financing for SMEs Around the World: Drivers, Obstacles, Business Models, and Lending Practices.- Policy Research Working Paper 4785. World Bank, Washington, DC.

Beck, T., Demirgüç-Kunt, A. \& Maksimovic, V. (2005a). Financial and Legal Constraints to Firm Growth: Does Firm Size Matter?, Journal of Finance, 60, pp. 137-7.

Beck, T.,Demirgüç-Kunt A. \& Levine R. (2005b). SMEs, Growth, and Poverty:Cross-Country Evidence, Journal of Economic Growth, 10, pp. 199-229.

Beck, T., Demirgüç-Kunt, A. \& Maksimovic V. (2008a). Financing Patterns Around the World: Are Small Firms Different? Journal of Financial Economics, 89, pp. 467-487.

Beck, T., Demirgüç-Kunt, A., Laeven, L. \& Maksimovic V. (2006). The Determinants of Financing Obstacles, Journal of International Money and Finance, 25(6), pp. 932-952.

Berger, A., Hunter, W. \& Timme, S. (1993). The efficiency of financial institutions: A review and preview of research past, present and future. Journal of Banking \& Finance, Volume 17, Issues 2-3, pp. 221-249.

Binks, M. \& Ennew, C.(1997). The Relationship between UK Banks and their Small Business Customers, Small Business Economics, 9, pp. 167-178.

Budina, N., Garretsen, H. \& Eelke de Jong (2000). Liquidity Constraints and Investment in Transition Economies: The Case of Bulgaria, Economics of Transition, 8, pp. 453-475.

Central bank of Estonia data base/ http://www.eestipank.ee/en/statistics

Central bank of Latvia data base/ http://www.bank.lv/en/statistics

Central bank of Lithuania data base/ http://www.lb.lt/statistical_data_tree

Clas, W. (1990). The incentive to acquire information and financial market efficiency. Journal of Economic Behavior \& Organization, Volume 13, Issue 3, pp. 347-365.

Djankov, S., McLiesh, C. \& Shleifer, A. (2006). Private Credit in 129 Countries, Journal of Financial Economics, Elsevier, vol. 84(2), pp. 299-329.

European Central Bank. (2011). Survey on the access to finance of SMEs in the euro area: Report on SME access to Finance Survey.

European Commission. (2009). Making public support for innovation in the EU more effective: Lessons learned from a public consultation for action at Community level, SEC(2009)1197 of 09.09.2009. 
Fama, E. (1970). Efficient Capital Markets: A Review of Theory and Empirical Work . Journal of Finance, 25(2), pp 383-417.

Fama, E. (1991), Efficient Capital Markets, II. Journal of Finance, 46(5), pp. 1575-1617.

Galindo, A. \& Schiantarelli F. (2003). Credit Constraints and Investment in Latin America.- RES Working Papers 4305, Inter-American Development Bank, Washington D.C.

Gros, D. \& Suhrcke M. (2000). Ten Years After: What is Special About Transition Countries?.European Bank Working Paper N. 56.

Hallberg, K. (2000). A Market-Oriented Strategy for Small and Medium-Scale Enterprises, Discussion Paper 40, International Finance Corporation

Hart, O. \& Moore J. (1994). A Theory of Debt Based on the Inalienability of Human Capital. Quarterly Journal of Economics. Vol. 109, pp. 841-879.

Hart, O. \& Moore, J. (1998). Default and Renegotiation: A Dynamic Model of Debt, Quarterly Journal of Economics. Vol.113,pp. 1-42.

Hutchinson, J. (2006). Comparing the Impact of Credit Constraints on the Growth of SMEs in a Transition Country with an Established Market Economy, Small Business Economics, 27, pp. 169179.

IADB (Inter-American Development Bank) (2004). Unlocking Credit: The Quest for Deep and Stable Lending, Baltimore, MD: Johns Hopkins University Press.

IAISWEB. (2011). Insurance Core Principles, Standards, Guidance and Assessment Methodology. Internet access:

http://www.iaisweb.org/_temp/Insurance_Core_Principles_Standards__Guidance_and_Assessment _Methodology_October_2011.pdf

IMF. (2000 a). Code of Good Practices on Transparency in Monetary and Financial Policies. Internet access: http://www.imf.org/external/np/mae/mft/index.htm

IMF. (2007 b). Code of Good Practices on Fiscal Transparency. Internet access: http://www.imf.org/external/np/fad/trans/code.htm

International Organization of Securities Commissions. (2010), Objectives and Principles of Securities Regulation. Internet access: http://www.iosco.org/library/pubdocs/pdf/IOSCOPD323.pdf

Jaffe, D. \& Russell, T. (1976). Imperfect Information, Uncertainty, and Credit Rationing. Quarterly Journal of Economics, Vol. 90, No. 4,pp. 651-666.

Konings, J., Rizov M. \& Vandenbussche H. (2003). Investment and Credit Constraints in Transition Economies: Micro Evidence from Poland, the Czech Republic, Bulgaria and Romania, Economics Letters, 78, pp. 253-258.

Leighton, V. (2005). Information efficiency in financial and betting markets. Cambridge University Press, pp. 387.

Mankiw, G., Phelps, E. \& Romer, P. (1995). The Growth of Nations, Brookings Institution Press, pp.275-326.

Meghana, A., Beck, T., and Demirgüç-Kunt, A. (2007). Small and Medium Enterprises Across the Globe, Small Business Economics, 29, pp. 415-434.

Peachey, S. \& Roe, A. (2004). ACCESS TO FINANCE, Oxford Policy Management. Internet access: http://www.microfinancegateway.org/gm/document-1.9.29564/22078_access_2_finance.pdf

Pittsburgh G-20 Summit “Leaders' Statement” at http://www.pittsburghsummit.gov 
Powell, A., Mylenko, N., Miller M. \& Majnoni, G. (2004). Improving Credit Information, Bank Regulation and Supervision: On the Role and Design of Public Credit Registries. Policy Research Working Paper 3443, World Bank, Washington, DC.

Pro Inno Europe, (2011). Feasibility study on new forms of EU support to Member States and Regions to foster SMEs Innovation Capacity No 55/PP/ENT/CIP/10/F/S01C016, Final Report. pp. 184. Internet access: www.innova-europe.eu.

Schiffer, M. \& Weder, B. (2001). Firm Size and the Business Environment: Worldwide Survey Results, Discussion Paper 43, International Finance Corporation, Washington, DC.

Scholtens, B. (1999). Analytical Issues in External Financing Alternatives for SMEs, Small Business Economics, 12, pp. 137-148.

Snodgrass, D. \& Biggs, T. (1996). Industrialization and the Small Firm: Patterns and Policies. San Francisco: International Center for Economic Growth.

Stephanou, C. \& Rodriguez, C. (2008). Bank Financing to Small and Medium- Sized Enterprises (SMEs) in Colombia, Policy Research Working Paper 4481. World Bank, Washington, DC.

Stiglitz, J. \& Weiss, A. (1981). Credit Rationing in Markets with Imperfect Information, American Economic Review Nr.71, pp.393-410.

Townsend, R. (1979). Optimal Contracts and Competitive Markets with Costly State Verification. Journal of Economic Theory. Vol. 21,pp. 265-293.

World Bank \& IFC Doing Business data base. Internet access: http://www.doingbusiness.org/reports/global-reports/doing-business-2013

World Economic forum data base. Internet access: http://www.weforum.org/issues/competitiveness0/gci2012-data-platform/

World Economic Forum. (2012), The Global Competitiveness Index 2012-2013 data platform. Internet access: http://www3.weforum.org/docs/WEF_GlobalCompetitivenessReport_2012-13.pdf 